\title{
Front Matter: Volume 11685
}

, "Front Matter: Volume 11685," Proc. SPIE 11685, Terahertz, RF, Millimeter, and Submillimeter-Wave Technology and Applications XIV, 1168501 (3 May 2021); doi: 10.1117/12.2596711

SPIE. Event: SPIE OPTO, 2021, Online Only 


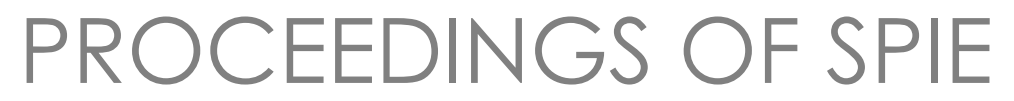

\section{Terahertz, RF, Millimeter, and Submillimeter-Wave Technology and Applications XIV}

Laurence P. Sadwick

Tianxin Yang

Editors

6-11 March 2021

Online Only, United States

Sponsored and Published by

SPIE

Volume 11685 
The papers in this volume were part of the technical conference cited on the cover and title page. Papers were selected and subject to review by the editors and conference program committee. Some conference presentations may not be available for publication. Additional papers and presentation recordings may be available online in the SPIE Digital Library at SPIEDigitalLibrary.org.

The papers reflect the work and thoughts of the authors and are published herein as submitted. The publisher is not responsible for the validity of the information or for any outcomes resulting from reliance thereon.

Please use the following format to cite material from these proceedings:

Author(s), "Title of Paper," in Terahertz, RF, Millimeter, and Submillimeter-Wave Technology and Applications XIV, edited by Laurence P. Sadwick, Tianxin Yang, Proceedings of SPIE Vol. 11685 (SPIE, Bellingham, WA, 2021) Seven-digit Article CID Number.

ISSN: 0277-786X

ISSN: 1996-756X (electronic)

ISBN: 9781510642058

ISBN: 9781510642065 (electronic)

Published by

SPIE

P.O. Box 10, Bellingham, Washington 98227-0010 USA

Telephone +1 3606763290 (Pacific Time) · Fax +1 3606471445

SPIE.org

Copyright (c) 2021, Society of Photo-Optical Instrumentation Engineers.

Copying of material in this book for internal or personal use, or for the internal or personal use of specific clients, beyond the fair use provisions granted by the U.S. Copyright Law is authorized by SPIE subject to payment of copying fees. The Transactional Reporting Service base fee for this volume is $\$ 21.00$ per article (or portion thereof), which should be paid directly to the Copyright Clearance Center (CCC), 222 Rosewood Drive, Danvers, MA 01923. Payment may also be made electronically through CCC Online at copyright.com. Other copying for republication, resale, advertising or promotion, or any form of systematic or multiple reproduction of any material in this book is prohibited except with permission in writing from the publisher. The CCC fee code is $0277-$ $786 \mathrm{X} / 21 / \$ 21.00$.

Printed in the United States of America by Curran Associates, Inc., under license from SPIE.

Publication of record for individual papers is online in the SPIE Digital Library.

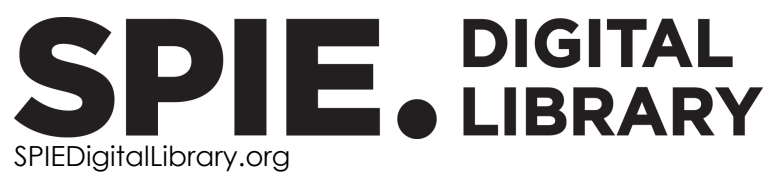

Paper Numbering: Proceedings of SPIE follow an e-First publication model. A unique citation identifier (CID) number is assigned to each article at the time of publication. Utilization of CIDs allows articles to be fully citable as soon as they are published online, and connects the same identifier to all online and print versions of the publication. SPIE uses a seven-digit CID article numbering system structured as follows:

- The first five digits correspond to the SPIE volume number.

- The last two digits indicate publication order within the volume using a Base 36 numbering system employing both numerals and letters. These two-number sets start with $00,01,02,03,04$, 05, 06, 07, 08, 09, OA, OB ... 0Z, followed by 10-1Z, 20-2Z, etc. The CID Number appears on each page of the manuscript. 


\section{Contents}

\section{THZ IMAGING AND SPECTROSCOPY}

1168505 Stable, compact terahertz ATR time-domain spectroscopy apparatus for quantitative solute measurements and real-time monitoring [11685-2]

$1168506 \quad$ Imaging using terahertz time-domain spectroscopy in motion [1 1685-3]

$1168507 \quad$ Reduction of surface morphology influence on THz reflection time domain spectroscopy for material classification by using multiple observation angles [1 1685-4]

THZ SOURCES AND DEVICES

11685 OC AIGaN/GaN heterostructures for plasma wave detection and emission in THz regime [11685-9]

INFRARED DEVICES, SOURCES, AND SYSTEMS

11685 OD Wavelength selective, polarization sensitive, and uncooled infrared detectors for solar infrared imaging [11685-10]

$116850 G$ Compact and robust mid-infrared laser-based gas sensor for portable and real-time measurements [11685-13]

OPTOELECTRIC DEVICES, SOURCES, AND SYSTEMS

$11685 \mathrm{OH} \quad$ Hydrogen-terminated diamond MESFETs: operating principles, static and dynamic performance, and reliability (Invited Paper) [1 1685-14]

$116850 \mathrm{~J} \quad$ Ultracompact silicon optomechanical cavities as optical upconverters of OFDM wireless signals [11685-16]

11685 OK Single-pixel UV image sensor based on 4H-SiC CMOS technology with gamma-ray irradiation resistance [11685-17]

$11685 \mathrm{OL} \quad$ Novel computational model for simulating integrated optoelectronic oscillators [11685-18] 
$116850 \mathrm{M}$ Terahertz-wave Nyquist wavelength division multiplexing communication utilizing integratedoptic spectrum synthesizer [11685-19]

11685 ON High-resolution spectroscopy of arbitrary light sources using frequency combs [11685-20]

11685 OP Photonic microwave and RF channelizers based on Kerr micro-combs [11685-22]

METAMATERIALS AND GRAPHENE

11685 OU Design of an optimized graphene plasmonic splitter utilizing higher-order mode propagation [11685-27]

EMERGING AREAS IN TERAHERTZ

$116850 \mathrm{X}$ THz spectroscopy of emerging materials for light driven processes and energy harvesting (Invited Paper) [1 1685-30]

SPECTROSCOPY, IMAGING, AND INTERFEROMETRY

1168511 Fitting of photoluminescence spectra for structural characterisation of high current density resonant tunnelling diodes for THz applications [1 1685-34]

1168514 Characterization of hollow-core-metal waveguide using broadband THz time domain spectroscopy for high-pressure and temperature sensor [11685-37]

1168515 Discrimination between cosmological and stellar phenomena by intensity interferometry [11685-38]

1168516 Measurement of moisture content in milk powder using terahertz time-domain spectroscopy [11685-39]

TERAHERTZ LASER SYSTEMS

11685 1C Stability of CW-THz wave using laser chaos [1 1685-45]

THZ TIME AND FREQUENCY DOMAIN AND EXTRACTION

$11685 \mathrm{IF} \quad$ Towards THz beam steering with integrated phased photomixer arrays [1 1685-48]

iv 
$116851 \mathrm{H} \quad$ Extraction of optical parameters of composite material for real-world THz application [11685-50]

$1168511 \quad$ Electrically-driven heterodyne detection of a multifrequency THz-wave with a photomixer [11685-60]

\section{OPTICAL THZ TECHNIQUES}

$116851 \mathrm{~J} \quad$ Tunable multi-channel optical true time delay using frequency interval tunable multiwavelength light source [11685-51]

$11685 \mathrm{lL} \quad$ Simultaneous estimation of thickness and refractive index by combining transmission and reflection measurements [1 1685-53]

$116851 \mathrm{M}$ A spatio-temporal finite difference time domain simulation technique to estimate terahertz pulse profile of a photo-conductive antennae [11685-54]

\section{APPLICATIONS AND MODELING OF THZ STRUCTURES}

1168510 A polarization-maintaining $\mathrm{THz}$ anti-resonant fiber based on the mode coupling between core and cladding [11685-56]

$116851 Q$ Terahertz waves polarization tunability in unaligned single-wall carbon nanotube thin film [11685-58]

POSTER SESSION

11685 is THz-based spectroscopy for accurate material identification [11685-61]

$116851 \mathrm{IT} \quad$ A new FPGA-based terahertz (THz) imaging device for multiphase flow metering [11685-62]

$116851 \mathrm{U}$ Super-resolution simulation of terahertz coded aperture imaging [11685-63] 
Proc. of SPIE Vol. 11685 1168501-6 Downloaded From: https://www.spiedigitallibrary.org/conference-proceedings-of-spie on 26 Apr 2023
Terms of Use: https://www.spiedigitallibrary.org/terms-of-use 